\title{
Obituary: Sven Hansbo
}

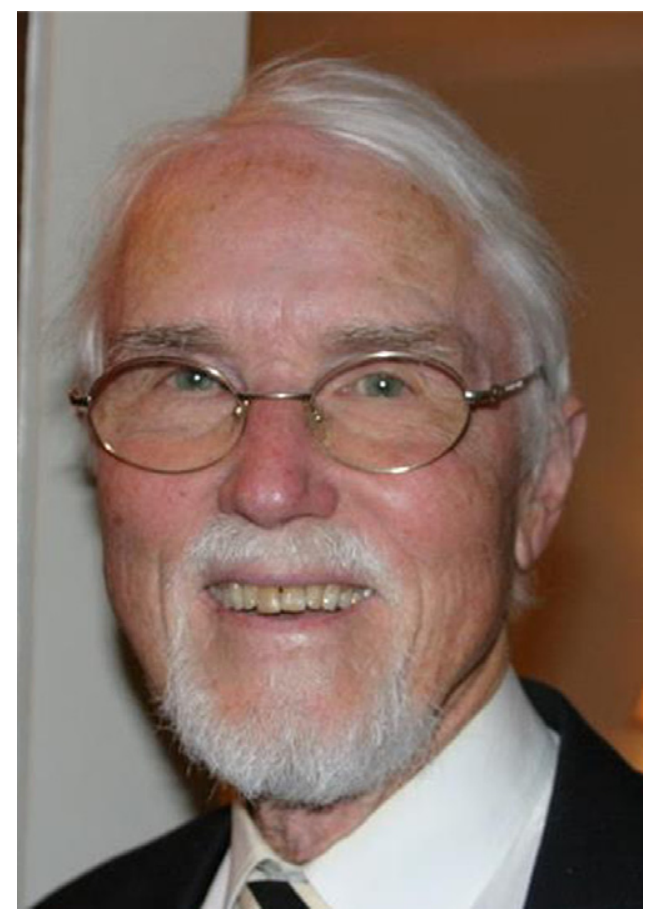

Professor Sven Hansbo, 1924-2018

It is with great sadness that we have to inform readers that Professor Sven Hansbo, Stockholm, Sweden, died peacefully on 8 January 2018, shortly after having celebrated his 93rd birthday.

Sven Hansbo was a monumental figure in Swedish geotechnical engineering. He was an unusually gifted man, appreciated for his warmth and professional competence by many colleagues and friends. He was a brilliant researcher and scientist, innovative and bold in his approach to the solution of problems, always with a positive attitude, especially encouraging younger colleagues. Sven also had a deep interest in, and talent for, art and especially literature. He appreciated his social life and delivered on many occasions - by heart - famous Swedish poetry.

Sven Hansbo was born in the small village of Nyed in Värmland, was brought up under simple circumstances in a family of peasants and became the first in his family to take a college degree. After graduation from Chalmers University of Technology $(\mathrm{CTH})$, Sven wanted to pursue a scientific career in mathematics, which became one of his major interests in life. However, by coincidence, he was offered a research position at the newly formed Swedish Geotechnical Institute where he conducted his ground-breaking research on vertical drains, for which he was awarded a doctoral degree.

Sven Hansbo became the first professor in geotechnical engineering in Sweden and established with great enthusiasm the geotechnical department at Chalmers. As a professor and scientific leader of the department, he was enthusiastic but at the same time thoughtful, innovative and full of new ideas. He was always available for discussions with graduate students and researchers, who benefitted from his wisdom, critical comments and advice.

In the early 1960s, Sven joined a leading Swedish consulting firm and expanded its geotechnical division to become the leading private geotechnical consultancy. During many years, he shared his time between consulting, research and teaching. He was involved in many large and complex foundation projects, where he had the opportunity to introduce new ideas. Long beyond his retirement age, he was active as a consultant, mentor and lecturer in Scandinavia and abroad. One of his specialties was deep foundation solutions on very soft, compressible clay. He became internationally recognised for his work on prefabricated drains, lime cement columns, dynamic compact and, in particular, his invention of 'creep piles' well before others realised the potential of load sharing between foundations and floating piles.

In spite of his scientific background, Sven Hansbo remained a genuine engineer with the ambition to challenge established technical solutions, always striving for better and more cost-effective alternatives. Within his area of expertise, ground treatment and piled foundations, he became recognised as a world leader and became part of an international network of leading experts, with whom he generously shared his ideas.

Of particular interest to Sven was the development of international and European standards, especially in the area of ground improvement (vertical drainage, deep mixing and soil nailing). But in his opinion, standards were not to be a restraint of innovative thinking, recognising the risk of limiting new ideas or innovative solutions.

Besides geotechnical engineering, Sven Hansbo was deeply engaged in developing the engineering profession and the construction industry in general. He was chairman of the Swedish Geotechnical Society (SGF) for 8 years and vice chairman of the Swedish Construction Association for 5 years. He was also chairman of the organising committee of the highly successful 19th International Conference on Soil Mechanics and Foundation Engineering, held in Stockholm in 1981. In recognition of his many contributions to geotechnical engineering, Sven Hansbo was made honorary member of SGF and awarded the SGF honorary prize. In connection with Sven's 90th birthday, SGF established the 'Sven Hansbo' prize acknowledging his outstanding contributions to Swedish geotechnical engineering. In 1973, Sven Hansbo was also awarded an honorary prize for the innovative application of load compensation in connection with floating pile foundations by the Stockholm Construction Association.

Professor Hansbo received several international awards, such as the Golden Award of Merits of the Academic Senate of the Warsaw Agricultural University 1986, the Polytechnica Gdanska Medal for promoting the scientific cooperation between Chalmers University of Technology and Polytechnica Gdanska 1995, and the prestigious Kevin Nash Gold Medal from the International Society of Soil Mechanics and Geotechnical Engineering 2009.

While being a widely recognised and respected authority in his field by colleagues and clients from all over the world, he was at the same time unpretentious and could speak in the language of the everyday man: 'talking to farmers in farmers' way', a clear link to his upbringing on a farm under humble circumstances. At festive occasions, for example at the Swedish Foundation Day or the memorable celebration of his 
90th birthday, he recited by heart many verses of the famous Swedish poet Fröding.

Many of his former students, colleagues, members of SGF and long-standing friends in Sweden and abroad feel the great loss of an extraordinarily gifted yet humble man, always friendly, positive and with a twinkle in his eyes. The passing of Professor Sven Hansbo leaves a large void in the geotechnical community in Sweden and abroad.

Gunilla Franzén, K. Rainer Massarsch and Göran Sällfors 